\title{
THE EFFECT OF ANOXIC ANOXIA ON THE HUMAN KIDNEY ${ }^{1}$
}

\author{
By EUGENE Y. BERGER, MORTON GALDSTON, AND SEYMOUR A. HORWITZ \\ WITH THE TECHNICAL ASSISTANCE OF ROSLYN JACKENTHAL \\ AND MARILYN PRUSS \\ (From the Research Service, Third New York University Medical Division, Goldwater \\ Memorial Hospital, Welfare Island, New York and the Department of Medicine, \\ New York University College of Medicine, New York, New York)
}

(Received for publication December 18, 1948)

Congestive heart failure is associated with reduction of renal blood flow and retention of salt and water. The possibility has been raised that these changes may result from the concomitant renal anoxia $(1,2)$. The present studies are concerned with the effect of anoxia on the human kidney under situations of normal cardiovascular dynamics.

\section{METHODS}

In subjects with normal cardiovascular and respiratory systems, an arterial blood oxygen tension of approximately $50 \mathrm{~mm}$. $\mathrm{Hg}$ was induced by the inhalation of 14 per cent oxygen. This concentration of oxygen was selected in order to induce a maximum degree of anoxia compatible with minimal changes in cardiovascular and respiratory dynamics (3). Observations of discrete renal functions were then made in these subjects and compared with renal functions while breathing room air. Observations were also conducted on emphysematous individuals who had arterial blood oxygen tensions of approximately $50 \mathrm{~mm}$. $\mathrm{Hg}$ while breathing room air and observations were repeated while breathing 100 per cent oxygen. In the latter cases, periods while breathing room air were considered to be anoxic periods and periods while breathing 100 per cent oxygen were considered control periods. In all cases, 20 to 45 minutes were allowed for equilibration following a change of oxygen concentration in respired air.

Glomerular filtration rate was measured as the inulin clearance and renal plasma flow as $p$-aminohippurate clearance, following the principles outlined by Smith (4). An intravenous infusion of saline containing inulin and sodium $p$-aminohippurate was administered at a rate of $3 \mathrm{ml} . / \mathrm{min}$. subsequent to an appropriate priming dose. Urine was collected in periods of 15 to 30 minutes through an indwelling multi-eyed catheter. At the end of each period the bladder was rinsed with distilled water. Urine samples for measurement of $\mathrm{pH}$ were collected and kept under oil. At the mid-point of each urine collection period, blood was drawn anaerobically from the femoral

1 This investigation has been aided by grants from the Josiah Macy Jr. Foundation and the Division of Research Grants and Fellowships of the National Institute of Health, U. S. Public Health Service. artery through an indwelling needle. Heparin was used as an anticoagulant. The renal data in the tables represent the means of three collection periods.

Since the inulin and $p$-aminohippurate were administered in an infusion, the addition of a small amount of normal saline to the circulating volume $(500 \mathrm{ml}$. over 3 hours) might be responsible for the observed changes in electrolyte excretion. To obviate this factor, the time relationship of the control to anoxic periods was varied. In $\mathrm{CH}, \mathrm{LS}, \mathrm{LB}, \mathrm{MH}$, and $\mathrm{MS}$, the control periods preceded the anoxic periods. In $\mathrm{KN}, \mathrm{DV}$, and $\mathrm{NG}$, the control periods followed the anoxic periods. MS was further studied to follow his return to the control levels.

Inulin was measured in urine and plasma by Harrison's modification (5) of Alving's method (6). p-Aminohippurate was measured in diluted urine and trichloracetic acid filtrates of plasma by the Bratton-Marshall reaction (7). Sodium and potassium were determined with an internal standard flame photometer (8). Chloride was determined according to Wilson and Ball (9); phosphorus according to Fiske and SubbaRow (10); ammonia according to Summerson's modification of the Van Slyke and Cullen procedure (11) ; $\mathrm{pH}$ with a Leeds and Northrup $\mathrm{pH}$ meter; urinary protein was determined by the micro-Kjeldahl technique using a trichloracetic acid precipitation.

Expired air was collected in a Tissot spirometer which recorded respiratory rate and volume. The mouth piece and nose clip were kept on the subject throughout the procedure except for a few minutes rest prior to a change in oxygen concentration in the inspired air. Arterial blood oxygen and carbon dioxide contents were determined by the method of Van Slyke and Neill (12), and tensions by the direct method of Riley (13). Respiratory gases were analyzed in a Haldane-Henderson apparatus and micro-Scholander gas analyzer (14).

The pulse rate and brachio-arterial blood pressure were recorded at five-minute intervals throughout any particular procedure. Mean arterial blood pressure levels were calculated by adding a third of the systolic and diastolic difference to the diastolic pressure.

With a view to minimizing the problem of anxiety, prior to the day of experiment the subjects were catheterized and were acclimated to breathing through a Tissot spirometer. The subject was not informed of changes in oxygen concentration during the experiment and gave no indication of having noticed the change. 


\section{OBSERVATIONS}

There were slight alterations in respiration and circulation during inhalation of 14 and 100 per cent oxygen (Table I). The changes in respiration were all within the error of measurement. The average pulse rate did not change significantly in four observations while it rose 8 to 14 beats during anoxia in the other five. The average mean blood pressure during the anoxic periods was not different from that of the control except in one instance when it rose $13 \mathrm{~mm}$. $\mathrm{Hg}$ during anoxia.

Renal plasma flow did not decrease during the anoxic periods. On the contrary, there was a tendency for it to increase. In observations in individuals with normal pulmonary function, three comparisons exhibited no appreciable change in renal plasma flow and four increased 13 to 20 per cent. In the two subjects with pulmonary emphysema, the administration of 100 per cent oxygen induced a fall in renal plasma flow; considering periods of breathing room air as the anoxic periods there was an increase in renal plasma flow of 29 per cent in each subject during anoxia. The filtration rate did not change appreciably during anoxia in four observations, increased 9 to 23 per cent in four, and decreased 19 per cent in one.

The interpretation of $p$-aminohippurate clearance as a measure of renal plasma flow is based on its almost complete extraction by the kidney. Under normal situations this extraction is at a maximum. A decrease in $p$-aminohippurate clear- ance during anoxia would be difficult to interpret in terms of renal plasma flow if the anoxia altered its extraction. However, the observed clearances increased and a change in this direction can be interpreted as an increase in effective renal plasma flow.

In the five comparisons where a change in pulse rate did occur, those which evidenced the greatest change in pulse rate did not have the greatest change in renal plasma flow. Since it has been observed that the increase in cardiac output which occurs during inhalation of anoxic gas mixtures results from an increase in pulse rate rather than stroke volume $(15,16)$, the observed changes in renal plasma flow are not considered to reflect changes in cardiac output.

There was an invariable and frequently marked increase in the rate of sodium and chloride excretion during anoxia (Table II). Sodium increased from a mean excretion of $162 \mu \mathrm{Eq} . / \mathrm{min}$. to $256 \mu \mathrm{Eq}$. $/ \mathrm{min}$. Chloride increased from a mean excretion of $161 \mu \mathrm{Eq}$./min. to $245 \mu \mathrm{Eq}$. $/ \mathrm{min}$. The urine flow tended to increase during anoxia presumably in consequence of the increased concentration of sodium and chloride in the urine. The magnitude of change in salt and water excretion exhibited little if any correlation with the magnitude of change in filtration rate or renal plasma flow.

Other electrolyte changes which occurred during anoxia were not as marked as those of sodium and

TABLE I

Effect of anoxia on respiratory, cardio-vascular, and renal dynamics

\begin{tabular}{|c|c|c|c|c|c|c|c|c|c|c|c|c|c|c|c|c|c|c|}
\hline \multirow{2}{*}{$\begin{array}{l}\text { Sub- } \\
\text { ject }\end{array}$} & \multirow{2}{*}{$\begin{array}{l}\text { Pulmonary } \\
\text { disease }\end{array}$} & \multicolumn{2}{|c|}{$\begin{array}{l}\text { Arterial } \\
\text { blood oxy- } \\
\text { gen tension }\end{array}$} & \multicolumn{3}{|c|}{$\begin{array}{l}\text { Respiratory } \\
\text { minute volume }\end{array}$} & \multicolumn{3}{|c|}{ Pulse rate* } & \multicolumn{3}{|c|}{$\begin{array}{l}\text { Mean arterial } \\
\text { blood pressure* }\end{array}$} & \multicolumn{3}{|c|}{ Inulin clearance $\dagger$} & \multicolumn{3}{|c|}{$\begin{array}{c}p \text {-Aminohippurate } \\
\text { clearancet }\end{array}$} \\
\hline & & $\begin{array}{l}\text { Con- } \\
\text { trol }\end{array}$ & $\begin{array}{l}\text { An- } \\
\text { oxia }\end{array}$ & $\begin{array}{c}\text { Con- } \\
\text { trol }\end{array}$ & $\begin{array}{l}\text { An- } \\
\text { oxia }\end{array}$ & Change & $\begin{array}{c}\text { Con- } \\
\text { trol }\end{array}$ & $\begin{array}{l}\text { An- } \\
\text { oxia }\end{array}$ & Change & $\begin{array}{l}\text { Con- } \\
\text { trol }\end{array}$ & $\begin{array}{l}\text { An- } \\
\text { oxia }\end{array}$ & Change & $\begin{array}{c}\text { Con- } \\
\text { trol }\end{array}$ & $\begin{array}{l}\text { An- } \\
\text { oxia }\end{array}$ & Change & $\begin{array}{c}\text { Con- } \\
\text { trol }\end{array}$ & $\begin{array}{l}\text { An- } \\
\text { oxia }\end{array}$ & Change \\
\hline 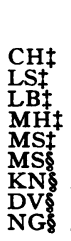 & $\begin{array}{c}\text { None } \\
\text { None } \\
\text { None } \\
\text { None } \\
\text { None } \\
\text { None } \\
\text { None } \\
\text { Emphysema } \\
\text { Emphysema }\end{array}$ & $\begin{array}{c}m m . \\
H g \\
97.6 \\
99.8 \\
97.0 \\
96.9 \\
95.0 \\
98.5 \\
93.3 \\
105 \% \\
108 \%\end{array}$ & $\begin{array}{c}m m . \\
H g \\
54.3 \\
50.1 \\
61.4 \\
49.0 \\
51.0 \\
51.0 \\
54.3 \\
57.5 \\
46.1\end{array}$ & $\begin{array}{c}\text { Lits/ } \\
\text { min. } \\
4.7 \\
8.1 \\
7.4 \\
7.3 \\
8.3 \\
7.6 \\
8.6 \\
8.3 \\
9.4\end{array}$ & \begin{tabular}{|} 
Litsl \\
min. \\
5.3 \\
7.3 \\
8.7 \\
8.9 \\
8.0 \\
8.0 \\
9.3 \\
8.4 \\
9.9
\end{tabular} & $\begin{array}{l}\text { Litsl } \\
\text { min. } \\
+0.6 \\
-0.8 \\
+1.3 \\
+1.6 \\
+0.3 \\
+0.4 \\
+0.7 \\
+0.1 \\
+0.5\end{array}$ & $\begin{array}{c}\text { Beats } \\
\text { lmin. } \\
79 \\
82 \\
59 \\
67 \\
77 \\
63 \\
72 \\
91 \\
82\end{array}$ & $\begin{array}{c}\text { Beats } \\
\text { Imin. } \\
82 \\
84 \\
62 \\
75 \\
77 \\
77 \\
80 \\
98 \\
94\end{array}$ & $\begin{array}{c}\text { Beats/ } \\
\text { min. } \\
+3 \\
+2 \\
+3 \\
+8 \\
0 \\
+14 \\
+8 \\
+7 \\
+12\end{array}$ & $\begin{array}{c}m m . \\
H g \\
89 \\
106 \\
95 \\
100 \\
116 \\
125 \\
102 \\
94 \\
89\end{array}$ & $\begin{array}{r}m m . \\
H g \\
88 \\
103 \\
96 \\
101 \\
129 \\
129 \\
101 \\
90 \\
86\end{array}$ & $\begin{array}{l}m m . \\
H g \\
=1 \\
=3 \\
+1 \\
+1 \\
+13 \\
+4 \\
=1 \\
=4 \\
-3\end{array}$ & $\begin{array}{r}\text { ml./ } \\
\text { min. } \\
95 \\
111 \\
101 \\
92 \\
72 \\
76 \\
111 \\
105 \\
107\end{array}$ & \begin{tabular}{|c} 
ml. \\
min. \\
90 \\
121 \\
82 \\
92 \\
84 \\
84 \\
117 \\
129 \\
114
\end{tabular} & $\begin{array}{c}\text { per cent } \\
-5.3 \\
+9.0 \\
-18.8 \\
0 \\
+16.7 \\
+10.5 \\
+5.4 \\
+22.8 \\
+6.5\end{array}$ & $\begin{array}{c}\operatorname{ml} . / \\
\min . \\
394 \\
601 \\
613 \\
382 \\
347 \\
316 \\
402 \\
371 \\
276\end{array}$ & $\begin{array}{c}\text { ml.l } \\
\text { min. } \\
389 \\
682 \\
546 \\
434 \\
356 \\
356 \\
483 \\
480 \\
356\end{array}$ & $\begin{array}{r}\text { per cent } \\
-1.3 \\
+13.5 \\
-2.8 \\
+13.6 \\
+2.6 \\
+12.6 \\
+20.1 \\
+29.4 \\
+29.0\end{array}$ \\
\hline
\end{tabular}

* Mean of consecutive five-minute observations.

$\dagger$ Mean of three observation periods, uncorrected to surface area.

$\ddagger$ Control periods preceded anoxic periods.

$\$$ Anoxic periods preceded control periods.

II Per cent hemoglobin saturation while breathing 100 per cent oxygen. Per cent saturation used in this instance because the measurement of tension by Riley's method is inaccurate at tensions over $110 \mathrm{~mm}$. $\mathrm{Hg}$. The values appear greater than 100 per cent because of the oxygen dissolved in the plasma. 


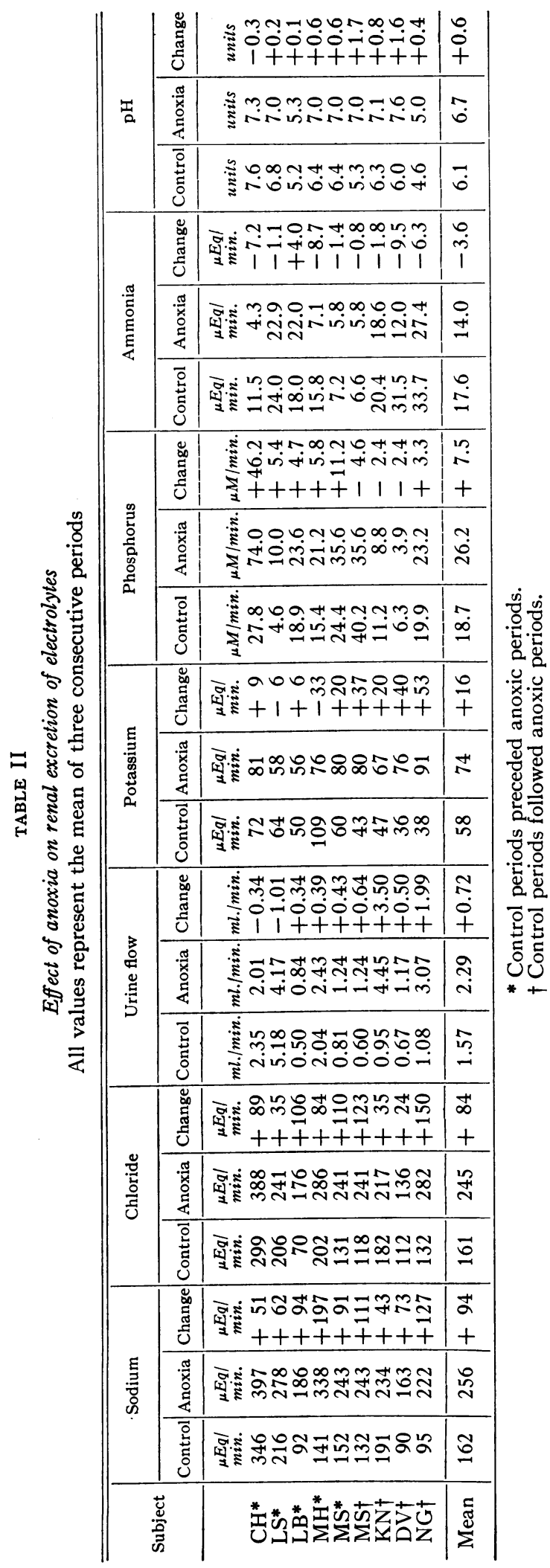

chloride. Urinary $\mathrm{pH}$ shifted to higher values in all observations except one but this subject had a control value of $\mathrm{pH}$ 7.6. Ammonia production decreased in all but one observation. Potassium excretion increased in all but two observations. Proteinuria did not develop during anoxic periods.

The phosphorus excretion usually increased as the experiment progressed irrespective of changes in blood oxygen tension.

\section{DISCUSSION}

A lowered arterial blood oxygen tension in subjects with normal cardiovascular function induced a marked increase in the renal excretion of sodium and chloride. In no instance did renal plasma flow decrease during anoxia. It would appear, therefore, that anoxic anoxia per se is not the cause of the retention of salt and water nor in the reduction of renal plasma flow observed in congestive heart failure.

If arterial blood oxygen tension is lowered in normal subjects, renal plasma flow and sodium and chloride excretion increase. If arterial oxygen tension is raised in anoxic emphysematous subjects, renal plasma flow and the excretion of sodium and chloride decrease.

The duration of anoxia was only one to two hours in the normal individuals in the investigation, but the emphysematous individuals had maintained a status of anoxic anoxia over a period of years. It is of interest that even in the latter subjects the effect of chronic anoxic anoxia on the kidney was readily altered.

The effect of lowering arterial blood oxygen tension beyond $50 \mathrm{~mm}$. $\mathrm{Hg}$ was not investigated as complicating changes in cardiovascular and pulmonary dynamics were likely. to be introduced. It is to be noted that in congestive heart failure and in disease states associated with arterial oxygen unsaturation, oxygen tensions seldom fall below $50 \mathrm{~mm}$. Hg.

In the normal subjects during anoxia, oxygen tension in inspired air was $106 \mathrm{~mm}$. Hg. McDonald and Kelley (17) investigated renal plasma flow and filtration rate in dogs at simulated altitudes where oxygen tensions in inspired air were 79.4 and $61.6 \mathrm{~mm}$. Hg. They found renal plasma flow to increase at higher altitudes, observations which are in accord with those reported here. 
The increase in urine flow in these studies confirms previous work in the rat (18), dog (19), and man (20) where polyuria has been observed at higher altitudes. Burrill et al. (21) reported a rise in the excretion of sodium and chloride during one hour exposures of adult males to simulated altitudes of 18,000 feet. Interestingly enough, they observed a compensatory retention of these ions following the exposure so that the 24 hour excretion was not altered.

The normal dog excretes excessive amounts of sodium and chloride when exposed to 10.5 per cent oxygen for 24 hours whereas the adrenalectomized animal fails to do so (22). Thorn (23) found rats treated with adrenal cortical extract survived longer at higher altitudes than untreated animals. These facts suggest the possibility that the changes in sodium and chloride observed in the present study may be in some way related to altered adrenal metabolism at low oxygen tensions. The behavior of potassium did not, however, conform to this hypothesis.

\section{SUMMARY}

Renal plasma flow in man did not decrease under situations of anoxia where arterial oxygen tension was lowered to about $50 \mathrm{~mm}$. $\mathrm{Hg}$. The most pronounced effect of lowered oxygen tension on renal tissue was the increased excretion of sodium and chloride. Anoxic anoxia alone, therefore, does not appear to be the cause of the reduction of renal plasma flow nor the retention of salt and water observed in congestive heart failure.

\section{ACKNOWLEDGMENTS}

The authors are indebted to Dr. Irving Leff and Dr. Herta Spencer for their valuable assistance in these studies.

\section{BIBLIOGRAPHY}

1. Futcher, P. H., and Schroeder, H. A., Studies on congestive heart failure. II. Impaired renal excretion of sodium chloride. Am. J. M. Sc., 1942, 204, 52.

2. Merrill, A. J., Edema and decreased renal blood flow in patients with chronic congestive heart failure. J. Clin. Invest., 1946, 25, 389.

3. Dripps, R. D., and Comroe, J. H., Jr., The effect of the inhalation of high and low oxygen concentrations on respiration, pulse rate, ballistocardiogram, and arterial oxygen saturation (oximeter) of normal individuals. Am. J. Physiol., 1947, 149, 277.
4. Smith, H. W., Lectures on the Kidney. University Extension Division, University of Kansas, Lawrence, Kansas, 1943.

5. Harrison, H. E., A modification of the diphenylamine method for determination of inulin. Proc. Soc. Exper. Biol. \& Med., 1942, 49, 111.

6. Alving, A. S., Rubin, J., and Miller, B. F., A direct colorimetric method for the determination of inulin in blood and urine. J. Biol. Chem., 1939, 127, 609.

7. Bratton, A. C., and Marshall, E. K., Jr., A new coupling component for sulfanilamide determination. J. Biol. Chem., 1939, 128, 537.

8. Barnes, R. B., Richardson, D., Berry, J. W., and Hood, R. L., Flame photometry. A rapid analytical procedure. Indust. \& Engin. Chem. (Analytical Edition), 1945, 17, 605.

9. Wilson, D. W., and Ball, E. G., A study of the estimation of chloride in blood and serum. J. Biol. Chem., 1928, 79, 221.

10. Fiske, C. H., and SubbaRow, Y., The colorimetric determination of phosphorus. J. Biol. Chem., 1925, $66,375$.

11. Hawk, P. B., Oser, B. L., and Summerson, W. H., Practical Physiological Chemistry. Blakiston Co., Philadelphia, 1947, Ed. 12, p. 828.

12. Peters, J. P., and Van Slyke, D. D., Quantitative Clinical Chemistry. Williams \& Wilkins Co., Baltimore, 1932, Vol. 2, p. 324.

13. Riley, R. L., Proemmel, D. D., and Franke, R. E., A direct method for determination of oxygen and carbon dioxide tensions in blood. J. Biol. Chem., 1945, 161, 621.

14. Scholander, P. F., Analyzer for accurate estimation of respiratory gases in one-half cubic centimeter samples. J. Biol. Chem., 1947, 167, 235.

15. Steele, J. M., Galdston, M., Messinger, W. J., Temchin, N., Rosenbluth, M. B., and Redisch, W., Sensitivity of the carotid sinus to anoxia. Final Report, Contract No. OEM cmr-130, 1943. Office of Scientific Research and Development, Washington, D. C.

16. Kety, S. S., and Schmidt, C. F., The effects of altered arterial tensions of carbon dioxide and oxygen on cerebral blood flow and cerebral oxygen consumption of normal young men. J. Clin. Invest., 1948, 27, 484.

17. McDonald, R. K., and Kelley, V. C., Some observations on effect of altitude anoxia on renal function. Project No. 506, School of Aviation Medicine. Randolph Field, Texas, 1948.

18. Silvette, H., Some effects of low barometric pressures on kidney function in the white rat. Am. J. Physiol., 1943, 140, 374.

19. Stickney, J. C., Northup, D. W., and Van Liere, E. J., Effect of anoxic anoxia on urine secretion in anesthetized dogs. Am. J. Physiol., 1946, 147, 616. 
20. Armstrong, H. G., Principles and Practice of Aviation Medicine. Williams \& Wilkins Co., Baltimore, 1939, p. 284.

21. Burrill, M. W., Freeman, S., and Ivy, A. C., Sodium, potassium and chloride excretion of human subjects exposed to a simulated altitude of 18,000 feet. J. Biol. Chem., 1945, 157, 297.
22. Lewis, R. A., Thorn, G. W., Koepf, G. F., and Dorrance, S. S., The role of the adrenal cortex in acute anoxia. J. Clin. Invest., 1942, 21, 33.

23. Thorn, G. W., Clinton, M., Jr., Davis, B. M., and Lewis, R. A., Effect of adrenal cortical hormone therapy on altitude tolerance. Endocrinology, 1945, 36,381 . 